\title{
Market Allocation and Enterprise Reform in the Primary Stage of Capitalism (1978-1992)
}

\section{Introduction}

During the Cultural Revolution, China's economy once again plunged into crisis. As in the Great Leap Forward, overinvestment by local actors in the last decade of the Maoist era had resulted in grave sectoral imbalances and inefficiencies. Political conditions offered no course for redress; mass movements had paralyzed state leadership and the strong anti-intellectualism of the Gang of Four had precipitated the collapse of China's academic institutions (Kou 2010). Political relations were normalized only after the death of Mao and the overthrow of the Gang of Four in the fall of 1976, allowing the state to formulate a strategy to deal with the economic malaise. ${ }^{69}$ The state's response came in the form of a ten-year plan, announced during the first session of the fifth National People's Congress in February 1978. The measures adopted under Mao's appointed successor Hua Guofeng diverged from the Maoist strategy of economic development in their strong endorsement of the "four modernizations" (si ge xiandaihua). ${ }^{70}$ Notwithstanding the novel emphasis on economic development through the absorption of advanced foreign technology, Hua's plan fell squarely within the remit of the socialist strategy of accelerated accumulation. Investment targets for the final eight years of the plan was to equal the total of the entire past 28 years. A total of 120 large-scale projects were to be constructed and 14 industrial bases were to be developed. In industry, steel production was the "key link"; output was to increase from 30 million tons to 60 million tons by $1985 .{ }^{71}$ In short, the new leadership's general strategy for

69 Economic problems had been further aggravated by the devastating Tangshan earthquake in the summer of 1976 . As a result, the growth rate of national income dropped by 2.3 percent.

70 The so-called "four modernizations", entailing the modernization of agriculture, industry, defense and science and technology, were first espoused by Zhou Enlai in 1963. Zhou (1980) stressed that the adoption of modern production technology and techniques was crucial to China's development.

71 Hua (1978). 
economic development was based on heavy industry-oriented growth (accelerated growth).

Economic growth rates in 1977 and 1978 were impressive at 7.6 and 11.7 percent respectively (NBS 2005, table 8). However, serious industrial bottlenecks were emerging. While Hua Guofeng and the Maoist faction ( fanshipai $)^{72}$ contended with the worsening structural problems of the economy, an opposing faction-consisting of leaders advocating sectoral adjustment and those in favor of market reform -was forming. These leaders had been instrumental in formulating and implementing the reform and readjustment policies of the early 1960, which had reinstated economic stability and growth after the disaster of the Great Leap Forward. At the Central Work conference preceding the third plenum of December $1978,{ }^{73}$ Hua suffered a decisive defeat at the hands of the emerging reform faction, allowing Deng Xiaoping to assume the position of paramount leader (Vogel 2011, p. 246). At the plenum Chen Yun was rehabilitated, to become a member of the top Party leadership. The readjustment and reforms subsequently introduced by Deng and Chen Yun marked the beginning of China's trajectory toward market socialism.

Many of the initial reforms introduced under Deng Xiaoping (and accompanying theoretical debate) harked back to the discussions of the liberal interludes of $1956-1958$ and especially $1960-1965$. However, from the latter half of the 1980s onward, reforms prompted economic developments unaccounted for by these earlier discussions, causing economic discourse to overflow the boundaries of Marxian analysis. Moreover, the expansion of economic theory was accompanied by a reappraisal of the role of economic theory itself. Whereas Mao's emphasis on the socialization of consciousness had implied the subjugation of economic theory to ideology, Deng's unequivocal emphasis on economic development prompted a pragmatist turn. As ideological issues gradually faded into the background (Misra 1998), the concepts of reform and readjustment became the central principles of China's economic paradigm. However, at the same time as these principles drove the development of the socialist market economy, economic and political conditions caused a bifurcation of the reform and readjustment programs, which had initially been

72 Hua and his conservative supporters were referred to as the fanshipai "lit. two whatevers faction," because of their insistence on "persisting in the conservation of whatever policy chairman Mao implemented, and; unwaveringly respecting whatever instructions Chairman Mao issued." See Renmin Ribao (1977).

73 The third plenum of the eleventh Central Committee of the CCP is of particular importance because it was at this session that the policies for the subsequent planning period were set out. 
regarded as natural complements, straining the alliance between Deng and Chen Yun.

\section{The Pragmatist Turn and the Liberalization of Economic Discourse}

The reforms introduced by Deng some 20 years after their initial conception in the 1950 s and early 1960 s were made possible only by a fundamental change in ideology. Marxist-Leninist doctrine held that socialist development depended on the comprehensive transformation of both the productive forces and the relations of production. Of these two conditions, Mao had consistently prioritized the latter. Efforts to achieve the socialization of consciousness reached their zenith during the last decade of Mao's rule. The Cultural Revolution, seeking to bring about a classless society and abolish the law of value, amounted to a repudiation of all theory of productive forces (i.e. the technical study of economic efficiency), of intellectualism and finally of the method of science itself (Lin 1981). Brock relates that, through mass experimentation, certain advances in production methods and technology were made (2009). However, it is indisputable that the Cultural Revolution on the whole seriously hampered the progress of Chinese economic practice and theory. Managerial positions within enterprise were abolished, and much economic planning suspended. The majority of academic institutions were closed, publication of major research journals ceased, and scholars and state leaders who had maintained "revisionist" opinions were sent to the countryside for ideological rectification, or imprisoned.

Following the heydays of the Cultural Revolution, Deng labored to normalize governance and politics, ${ }^{74}$ reinstate the managerial supervision of production and the policy of "to each according to one's labor" (an lao fenpei), ${ }^{75}$ and promote economic modernization. ${ }^{76}$ This pitted him against the Gang of Four, who, after the dissolution of the Small Leading Group for Cultural Revolution

74 Deng himself had been ousted from government in 1969. However, Zhou Enlai's support, against the backdrop of worsening economic imbalances in the 1970s, allowed Deng to return to state affairs in 1973 .

75 The concept of "to each according to one's labor" stood in opposition to the capitalist distributive principle of "to each according to one's capital" (an zi fenpei).

$7_{6}$ In 1975, Zhou had once again proposed his four modernizations, arguing that science and technology constituted the "major productive force," "Zhou Enlai zai si jie da hui baogaozhong chongshen 'si ge xiandaihua'” (1975). Deng strongly supported Zhou's efforts. For this and subsequent documents concerning the proceedings of the National People's Congress see <http://cpc.people.com.cn/GB/64162/64168/index.html>. 
(wenhua da geming lingdao xiaozu) in 1969 (McFarquhar and Schoenhals 2006), had become the de facto representatives of the radical faction within Party-state leadership. Blaming Deng for the popular unrest following Zhou Enlai's death in 1976, the Gang of Four launched the anti-Deng campaign (Dietrich 1998). A special report in the People's Daily, commenting on Deng's proposals on the reorganization of Party, and industry and science, ${ }^{77}$ argued that "[these proposals] reflected Deng's anti-revolutionary and revisionist character... [They] are ironclad proof of the continuing existence of capitalist roaders" (Hongqi 1976).

These condemnatory criticisms prevented Deng from assuming the role of paramount leader upon Mao's death in September 1976. Rather, that position was bequeathed to Hua Guofeng, who was ideologically close to Mao. Huawhile declaring the Cultural Revolution a victory for the Chinese people-was, however, quick to denounce the Gang of Four, who were contending the state leadership's political authority. Jiang Qing and her associates were arrested in October 1976. Political and public discourse in the subsequent period strongly repudiated radical rhetoric. In the wake of the turmoil and economic imbalance of the Cultural Revolution, the role of ideology within governance also became the subject of intense debate. In May 1978, Guangming Ribao published an essay at the behest of Party leadership. The piece commented that through their manipulation of public opinion, the Gang of Four had obfuscated objective measures of truth. Subsequently, people should no longer recourse to rhetoric or theorizing without empirical foundation. "Practice," stated the author, "is the sole criterion of truth." The epistemological perspective adopted by the state claimed to constitute a "liberation of thought" (sixiang jiefang) removed from the stringent ideological constraints of the Cultural Revolution and allowing for the continuation of the discussion on the law of value and the role of market allocation, which had been suspended for a decade.

Although, in the late 1970s, reforms and readjustment were once again topics of fervent debate, many leaders and academics continued to resist notions of decentralization and market allocation on grounds that such policies stood in direct opposition to the principles of socialism. In an address to the fourth meeting of the fourth plenary session of the eleventh Central Committee, Ye Jianying - who at the time served as chairman of the Standing Committee of the National People's Congress - charged that the Gang of Four had "completely

77 The documents in question are "Lun quan dang guan guo ge xiang gongzuo de zonggang" (1977); "Guanyu jiakuai gongye fazhan de ruogan wenti" (1977)]; and "Zhongguo kexueyuan gongzuo huibao tigang" (1977), jointly referred to by the Gang of Four as the "three poisonous weeds." 
inverted the relationship between subjectivism and objectivism, consciousness and material conditions and grossly exaggerated the revolutionary function of socialist consciousness in the development of society; of the superstructure in establishing the economic foundation; ${ }^{78}$ and of the productive relations in developing the productive forces." While China had already established the basic features of socialism, Ye stated, both economy and society remained underdeveloped (Ye 1979). In June 1981, the CCP officially endorsed the concept of the "primary stage of socialism" (shehui zhuyi chuji jieduan), stating that "the completion of the socialist system would be a tortuous process." ${ }^{79} \mathrm{By}$ emphasizing that the trajectory toward socialism would be long and arduous, the Party-state refuted the possibility of achieving the transition through revolutionary means. Rather, the development of the productive forces was the primary condition for the realization of socialist society. As a result, the transition of power from Mao to Deng was paired by a gradual shift in emphasis within the economic paradigm from the socialization of consciousness to the development of material conditions.

Ironically, it seems unlikely that this reversal in prioritization of the social and technical factors, and the abolishment of the Maoist principle of continuous revolution, would have been possible without the Gang of Four. The gang's actions in the first half of the 1970s weakened support for the radical faction and caused mounting popular dissent, creating the political scope for reform and readjustment. Moreover, the gang's role in the Cultural Revolution allowed Deng and other reform-minded leaders to denounce the politics of mass struggle without directly criticizing Mao.

\section{Early Reforms and Readjustment (1978-1986)}

\section{Chen Yun's Reforms Vindicated}

The vindication of state leaders and economists who had championed reforms in the Maoist era, allowed for the proposals outlined by Chen Yun some two decades earlier to be reintroduced in academic and policy discourse. Issues of price formation and the law of value were once again intensely debated. Hu Qiaomu, president of the Chinese Academy of Social Sciences (zhongguo

${ }_{78}$ In Marxian theory, the "superstructure" refers to the political system, institutions and culture, i.e. those elements of society that are not directly pertained with, but nevertheless play an indispensable supportive role in economic production. See the preface to Marx (1904).

"Guanyu jianguo yilai dang de ruogan lishi wenti de jueyi" (1981). 
shehui kexueyuan), voiced his strong support for the expansive operation of the law of value in an article in China's leading newspaper People's Daily (Hu 1978). In a refutation of Stalin's insistence on limiting the operation of the law of value to the sphere of national accounting, Hu argued that rational economic planning could only be achieved by allowing the law of value to exert its regulatory function in price formation. He furthermore insisted that the supposition that the laws of value and planned proportionate development were antagonistic was erroneous. What separated capitalist economies from their socialist counterparts was not the existence of the law of value, but rather the spontaneous and anarchistic operation thereof. Hu's perspective resonated with many of China's prominent economists (Liu, G. 1980; see Liu and Zhao 1979; Sun 1979, pp. 346-370) and policymakers.

In line with Chen Yun's proposals, experimentations with market allocation focused initially on the rural economy. The household responsibility system (jiating lianchan chengbao zerenzhi), introduced on a trial basis in 1979, allowed farmers to retain and sell for a profit any output above state-contracted quota. Introduction of the household responsibility system also allowed peasants to engage in non-agricultural production, providing a means to alleviate the problem of idle rural labor. By way of the 1979 "Decision on Certain Issues regarding Accelerated Agricultural Development," central government explicitly endorsed and encouraged the development of so-called township and village enterprises (TVEs, xiangzhen qiye). However, the expansion of TVEs was primarily driven by peasants and local government. Localities had been given authority to tax TVE sales and retain fiscal revenue beyond a negotiated proportion remitted to the center. As a result, local government acquired a strong interest in the fortunes of the TVEs (Chang and Wang 1994; Kung and Lin 2007). Since the emphasis under Mao had been on the development of heavy industry, bureaucratic interest in the agricultural sector was marginal, and therefore agricultural reforms met with little resistance (Shirk 1993). However, within public industry resistance to market reforms was considerable. As a consequence, within public industry prices continued to be determined by plan.

The debate concerning the decentralization of financial responsibility to enterprise resurfaced in tandem with the discussion of price formation and the law of value. Early proposals advocated the devolution of financial and operational authority to the industrial workforce (Dong 1979; Jiang 1980). The notion of collective management, however, failed to gain widespread support, as policymakers feared that workers would lack the requisite expertise. Rather, the state promoted the view that financial rights and responsibility ought to be invested in enterprise. Accordingly, management would be accountable for enterprise profits and losses and would be allowed to independently 
allocate its funds and engage in exchange (Hsu 1989). ${ }^{80}$ Experimentation with the extension of managerial authority commenced in the fall of 1978. By the fall of 1980, 6,6oo enterprises throughout the country, roughly accounting for 60 percent of industrial output, were granted the so-called "eight rights" of the Sichuan "experiment" (Tian 1981). This policy allowed soes to retain part of their profits, which could be used to fund the expansion of production. Enterprises were also allowed to engage in market production, provided they fulfilled stipulated quota, and were eligible to engage in the sale and purchase of products on international markets. Finally, enterprises were given greater discretion in their dealings with the workforce, and could issue individual bonuses to reward excellent performance or fire workers in case of grave misconduct (ibid.).

\section{Opening Up: China's Special Economic Zones}

While, within discussions on economic development, emphasis was on readjustment and reform, opening up (kaifang), that is, the reestablishment and expansion of international trade relations, constituted another major part of Deng's initiatives. The most salient representation of the strategy of opening up was arguably the development of the special economic zone (sEz) (jingji tequ). Throughout the 1980s, a number of coastal cities and the province of Hainan were designated as sites with expanded autonomy for Chinese enterprises and preferential conditions for foreign investors. Two factors spurred the conception of these SEzs. First, the zones were to be employed as a testing ground for reform policies (Xu 1981). Self-contained and effectively insulated from the main body of the Chinese economy, the zones would allow the Chinese state to appraise the implications of greater enterprise autonomy and the liberalization of production and trade in both manufacturing and services. In choosing relatively remote and underdeveloped areas, the potential downsides of such experimentation could be easily contained (Heilmann 2008). ${ }^{81}$ The immediate motivation for the introduction of the SEzs, however, was provided by the objective of industrial modernization. In the 1950s, Mao had argued that socialist industrialization could not be realized by relying on the

8o The notion of investing financial accountability in enterprise was not without its detractors. Economists such as Jiang Xuemo argued that, without the completion of price rationalization, the transfer of financial authority to enterprise would not promote the efficient utilization of capital; see Hsu (1989).

81 It has been maintained that subsequently a pattern emerged wherein local experimentation preceded national policymaking, accounting for the incremental quality of reforms, see Heilmann (2008); Qian, Roland and Xu (2006). 
transfer of advanced production technologies and methods from imperialist nations, and that it was necessary to adopt a strategy of self-determination and self-reliance (dulizizhu, zili gengsheng) (Mao 1992, p. 273). After the SinoSoviet split in 196o, China's inward orientation intensified, although Zhou Enlai repeatedly objected to China's self-imposed exile from the international economy (Zhou 1997, p. 226). Following the heyday of the Cultural Revolution (lasting from 1966 to 1969), Zhou was able to push forward the development of export commodity production bases, which came to serve as a precedent for Deng's SEZs (Stoltenberg 1984). However, up until the defeat of the radical faction in 1978, the antipathy toward international trade continued to prevail. As a result, Chinese industrialization during the Maoist era had to rely on comparatively backward technology.

This changed during Hua Guofeng's interregnum, when the "four modernizations" began in earnest. From July to September 1978, the issue of the rate of modernization was intensively discussed. State leadership concluded that a new Great Leap was required in order to rapidly improve the productivity of Chinese industry. Accordingly, within the Ten Year Plan, major outlays were made for the central procurement of foreign, advanced production technology (Li 2007). The strategy was not met with unequivocal approval. Certain economists and state leaders considered reliance on the import of turnkey installations imprudent. They argued that an emphasis on large-scale construction of new capital would aggravate sectoral imbalances. Moreover, it was wondered whether new technology could be effectively absorbed so as to ensure a commensurate upturn in productivity (Lin 1981). Chen Yun insisted that the modernization of industry ought not to rely on a small number of massive projects, but should rather focus on a comprehensive reorganization and technological transformation of extant production capacity. Indeed, central outlays for newly installed modernized production capacity were significantly scaled back the following year.

It was within the context of technological transformation under conditions of decreased central spending on capital construction that discussions regarding the sEzs emerged. Two diverging conceptions were initially put forward. The first - a relatively straightforward extension of the commodity production bases of the early 1970s - sought to emulate the export-oriented model of industrialization that had been adopted in, amongst other countries, Japan and South Korea in their initial stages of development. Concentrated in relatively developed economic areas, these zones would focus on exploiting their labor cost advantages in the manufacture of commodities that could be traded for advanced technologies on the international market (Wong 1987). The second conception sought to stimulate industrial modernization through 
the attraction of foreign capital and technology. Through joint production, Chinese firms would be able to access advanced production methods and equipment. Moreover, increased foreign investment would expedite industrial modernization while relieving the fiscal burden of the central state. Searching for a model that could advance both industrial modernization and promote the reform program, Deng Xiaoping ardently supported the latter perspective.

In July 1979, the administrators of Guangdong and Fujian province jointly drafted a proposal for the establishment of a SEZ in Shenzhen and Zhuhai, with another two such zones to be established in Shantou and Xiamen pending evaluation of the initial outcomes. ${ }^{82}$ In August of the following year, the State Council issued standardized regulations for the Guangdong sEzs. The central state would be directly responsible for the administration of the zones, but would for the most part refrain from interfering in production and trade. Foreign enterprises operating in the zones could engage in direct investment or joint ventures with Chinese enterprise. These firms would enjoy a variety of preferential conditions, such as: (1) reduced prices for land; (2) lowered enterprise and output taxes-with additional reductions for firms making large or long-term investments or producing high-tech goods-and (3) preferential pricing for Chinese raw materials or machinery. ${ }^{83}$

Plans for establishing SEZs also included the island of Hainan, which at the time was administratively part of Guangdong province (Brødsgaard 2009). Since Hainan, compared to the other zones, comprised a much larger areaonly slightly smaller than Taiwan - these plans were potentially even more farreaching than the decision to establish four other zones in Shenzhen, Shantou, Xiamen and Zhuhai. In order to discuss ways of bringing Hainan's future development into line with general reform and open-door policies, a conference on the so-called Hainan Island Problem was held in Beijing in June-July 1980. The conference was called by the State Council and included leading officials from Guangdong province and Hainan administrative region as well as from a number of central ministries and commissions such as the State Agricultural Commission and the Ministries of Agricultural Reclamation, Forestry, Water Resources and Electric Power, Civil Affairs, Finance and Communication. Top leaders such as Zhao Ziyang, Wan $\mathrm{Li}, \mathrm{Gu} \mathrm{Mu}$ and Bo Yibo took part in the conference and issued "important instructions." According to the State Council's summary of the meeting (henceforth known as "circular 202"), it was decided to grant Hainan more autonomy in the area of foreign

\footnotetext{
82 "Guangdong shengwei he Fujian shengwei guanyu duiwai jingji huodong shixing teshu zhengce he linghuo cuoshi de baogao" (1979).

83 "Guangdong sheng jingji tequ tiaolie" (1980).
} 
economic activities. The island was to retain a certain percentage of foreign exchange earned and to be permitted "relatively large jurisdictional control." 84 It was specifically mentioned that Shenzhen's and Zhuhai's experiences could be used as a reference for Hainan's future development. In sum, a number of measures and policies were to be adopted in order to expand local economic autonomy. Some of these measures addressed the need to stimulate Hainan's backward agricultural sector; others dealt with foreign economic issues and resembled earlier initiatives taken in Shenzhen and Zhuhai SEzs.

Provincial officials in Guangdong also supported the idea of giving Hainan more autonomy and possibly developing a new SEZ on the island. Ren Zhongyi, who had replaced Xi Zhongxun as first Party secretary of Guangdong, was particularly in favor of accelerating the economic development of Hainan. ${ }^{85}$ In November 1981 the Party committee of Guangdong issued a circular (yuefa), which stipulated the adoption of preferential measures in Hainan vis-à-vis foreign joint ventures, such as a tax holiday, low prices in connection with rental of land and buildings, advantageous procedures by import of production materials, retention of foreign exchange, cheap labor power and so on. ${ }^{86}$ This was believed to greatly facilitate the inflow of foreign direct investment (FDI). As one local official explained in 1982: "We can even offer better terms than in Shenzhen. In joint ventures we can provide cheaper labour power and land than Shenzhen" (Brødsgaard 2009, p. 16).

However, local officials' attempts to turn Hainan into an SEZ similar to Shenzhen were thwarted by conservative leaders in Beijing. They did not object to Guangdong province allowing Hainan more autonomy, but they hesitated to go all the way and formally declare Hainan an SEz. In fact, key leaders such as Chen Yun and Li Xinnian had all along expressed reservations concerning the zone policy. They were not ready to support the establishment of yet another zone, which, in terms of geographical size and population, would dwarf those that the center had already decided on. However, in 1983, Zhao Ziyang, supported by Deng Xiaoping, was able push the Party Central Committee and the State Council to issue a new circular on Hainan's development. The circular specified the powers the center and Guangdong province were prepared to give Hainan in areas concerning direct foreign investment and the establishment of joint ventures with foreign participation. In general, Hainan acquired all the autonomy in foreign trade and investment that had earlier been given

\footnotetext{
84 "Hainan dao wenti zuotanhui jiyao" (1980).

85 This section on establishing a SEZ on Hainan builds on Brødsgaard (2009).

86 "Zhonggong Guangdong shengwei, Guangdong sheng renmin zhengfu guanyu jiakuai Hainan dao kaifa jianshe jige wenti de jueding" (1985, pp. 103-119).
} 
to Shenzhen and the other SEzs, although the island had not yet formally been declared such an entity. It had become a "bu shi tequ de tequ," a special zone which is not a special zone (Li and Zhu 1988). Clearly it was only a matter of time before Hainan would be declared a SEZ in name, similar to the other four zones established in 1980.

However, corruption and especially the so-called "Hainan car scandal" shattered the dynamism of the Hainan reformers and gave the conservatives good arguments for slowing down the process. The establishment of the sEzs raised concerns among conservatives, who believed that market-based production and exchange within the sEzs undermined the socialist character of the Chinese economy. Moreover, they charged that, by allowing foreign enterprises to appropriate part of the surplus value of Chinese labor, the SEzs had brought about a novel form of imperialism. Skeptics of the establishment of sEzs could draw on powerful support, especially from Chen Yun and Li Xiannian, who indicated their reservations by never visiting any of the zones. Proponents of the zones, however, argued that the operations of foreign enterprises operating within the zones were subject to administration by the Chinese state, and thus constituted a regulated form of state capitalism. Since the exchange between these foreign enterprises and Chinese firms was based on principles of equality and self-determination, concerns regarding imperialist expropriation were deemed unfounded (Xu 1981). Proponents of the zones were supported by Zhao Ziyang and Hu Yaobang and especially Deng Xiaoping. They believed that the rapid expansion of the SEzs would not only advance industrial modernization but could also promote the reform program by providing a testing ground for reform policies (Xu 1981). Self-contained and effectively insulated from the main body of the Chinese economy, the zones would allow the Chinese state to appraise the implications of greater enterprise autonomy and the liberalization of production and trade in both manufacturing and services. In choosing relatively remote and underdeveloped areas, the potential downsides of such experimentation could be easily contained (Heilmann 2008). ${ }^{87}$ In the early 1980s, the state forged ahead with the establishment of SEZs in Shantou and Xiamen, and the Seventh Five Year Plan (1985-1990) designated the coastal SEZs the beachhead of economic modernization. ${ }^{88}$

87 It has been maintained that subsequently a pattern emerged wherein local experimentation preceded national policymaking, accounting for the incremental quality of reforms (see Heilmann 2008; Qian, Roland and Xu 2006).

88 "Zhonghua renmin gongheguo jingji he shehui fazhan diqi ge wu nian jihua (zhaiyao)" (1986). 
In 1984 it was decided to give 14 cities along the coast the status of so-called "open cities." 89 Special policies were introduced to attract foreign investment, although the open cities never obtained the full package of preferential policies that the four SEZs were granted. In mid-1987, Deng divulged, in a discussion with a Yugoslavian delegation, that he intended to push forward with the idea of developing Hainan into an official SEz (Brødsgaard 2009). ${ }^{90}$ Subsequently, the State Council suggested that Hainan should no longer be part of Guangdong province but should be granted the status of an independent province, and fiscal and operational responsibilities would be decentralized accordingly. This implied, first, that enterprises in Hainan directly administered by the center or by the provincial authorities of Guangdong province were to be taken over by the new Hainan provincial government, although the center would continue to offer support in terms of investment, subsidies and raw materials. Importantly, plans for the further development of Hainan's economy would be required to be financed through Hainan's own resources and foreign investment, and not by increased investment from the center. Government intervention in foreign investment and development of an economic sector with foreign participation would be reduced even beyond that in the other SEzs. Indeed, under the auspices of Deng, Hainan was to become a testing ground and model for regional and bureaucratic reform for the whole country (quanguo sheng yiji jiegou quanmian gaige de shidian danwei). ${ }^{91}$ Although the Tiananmen debacle would momentarily detract from the emphasis on reform and opening up, in 1992 the SEzs would once again invigorate the reformist drive for decentralization and internationalization.

\section{Readjustment}

While reform of the mechanisms of allocation and the administration of enterprises eventually became the dominant theme in the era of Deng, and China's gradual integration into the international economy would have global implications, the more immediate concern in the initial post-Mao period was with the adjustment of the investment ratio and sectoral redistribution. Hua's

89 The 14 open cities were Dalian, Qinhuangdao, Tianjin, Yantai, Qingdao, Lianyungang, Nantong, Shanghai, Ningbo, Wenzhou, Fuzhou, Guangzhou, Zhanjiang and Beihai (Brødsgaard 2009, p. 33).

9o Yugoslavia was of particular interest to China's reformist leaders and economist because it had embarked on a course of socialist market reforms as early as the 1950s.

91 See "Zhonggong zhongyang, guowuyuan guanyu jianli Hainan sheng ji qi choujian gongzuo de tongzhi—zhongfa 23 hao, 1987" (1998, pp. 7-10). 
economic policies had perpetuated the Maoist-era pattern of accelerated accumulation, and the majority of government outlays had been allotted to projects in heavy industry. Additionally, between 1976 and 1978, the rate of gross fixed capital accumulation had climbed to an average 29 percent. The third plenum, held in December 1978, issued a comprehensive set of policies that sought to ensure a decisive break with the Fel'dman-Preobrazhensky model. A first host of policies focused on the attenuation of the price scissors. First, government procurement quota of grain would remain at the level of the period 1971-1975. Moreover, the prices at which government procured agricultural commodities were increased by an average 22.1 percent, and the price for the amount purchased above the quota by an additional 50 percent (Lin 1992). At the same time, prices for agricultural producer goods (machinery, fertilizer and pesticides) were reduced by some 10 to 15 percent between 1979 and 1980 .

In addition to the attenuation of the price scissors, preparations were made to significantly decrease and redistribute investments in capital construction. An editorial in the People's Daily announced that this would imply a scaling down of capital construction, primarily involving the iron and steel sector of heavy industry (Renmin Ribao 1979). At the conference for national capital construction in March 1979, the decision was made to terminate any industrial project that had been initiated without ensuring adequate supplies of capital and labor or fell short of central technological, environmental and efficiency-related criteria. Thus, only a fraction of the 120 large-scale projects detailed in the Ten Year Plan were to be completed by 1985 (the timeframe set out originally). Besides excessive and careless investment in heavy industry, the inefficacy of the strategy for economic modernization was attributed to the neglect of basic infrastructure. Therefore, the director of the State Capital Construction Commission, Han Guang, pledged to use a greater proportion of funds for the development of construction, transportation and energy (State Statistical Bureau 1979).

Although these measures proved successful in reducing budgeted funds for capital construction, they had but a marginal influence on the overall pattern of accumulation (see Table 4). The problems in achieving sectoral adjustment were largely due to decentralization. The "eight rights" policy had allowed enterprises to autonomously engage in the expansion of production capacity. Moreover, the devolution of operational authority to enterprise had diluted the influence of local government and had therefore met with strong resistance. Reforms had only been able to proceed through a quid pro quo where the loss of local authority over enterprise had been compensated by increasing provinces' discretion in raising and allotting fiscal revenues (Shirk 1990). Local 


\begin{tabular}{lcl}
\hline & $\begin{array}{l}\text { Central state investment in capital } \\
\text { construction/GDP }\end{array}$ & GFCF/GDP \\
\hline 1978 & 12.47 & 29.46 \\
1979 & 10.99 & 28.38 \\
1980 & 7.67 & 29.09 \\
1981 & 5.30 & 27.38 \\
1982 & 5.08 & 28.24 \\
1983 & 5.80 & 28.90 \\
1984 & 6.30 & 29.79 \\
1985 & 6.17 & 29.64 \\
\hline
\end{tabular}

SOURCE: CALCULATED FROM NBS (2005, TABLES $6,10,18)$.

government and soes used their increased financial prowess to fund the expansion of productive capacity. Increased industrial investment by local government and enterprise offset reduced central expenditure on capital construction, so that the rate of GFCF remained essentially unchanged (see Table 4).

The initial departure from the Fel'dman-Preobrazhensky paradigm of accelerated industrialization had been made possible through a coalition of proponents of sectoral readjustment and advocates of decentralization and market allocation. ${ }^{92}$ However, readjustment and reform proved incompatible; decentralization of fiscal power frustrated central attempts to adjust sectoral relationships or influence the rate of accumulation. Deng's policies had followed the guidelines for reform and readjustment set out in the economic discourse of the late 1950s and especially the early 196os. Those discussions had not anticipated the antagonism between decentralized investment and the development of agriculture. Nor had they considered the conjunctural problems that attended market-driven investment. Accordingly, in the early 1980s, the long-standing debate on sectoral relations and the rate of accumulation

92 As reflected in the new official shibboleth of economic policy adopted in 1978: "readjustment, reform, consolidation and improvement" (tiaozheng, gaige, zhengdun, tigao), thus substituting the previous focus on the concentration of control with one on decentralized allocation. 
ushered in a comprehensive reevaluation of the respective roles of regulation by central plan and market allocation.

\section{Reform and Recentralization, Balanced and Accelerated Growth}

The antagonism between the goals of readjustment and reform aroused considerable debate among Chinese policymakers and economists. An influential piece in the Chinese daily Guangming Ribao stated that the traditional strategy of accelerated accumulation had been characterized by low efficiency and had failed to significantly raise the standard of living (Pei, Liu and Li 1980). For example, according to the Guangming Ribao article, per capita grain consumption was 205 kilograms in 1956, but in 1978 it had actually dropped by 10 kilograms. Per capita average consumption of cotton cloth had remained stagnant, totaling 8.3 square meters in 1956, and 7.6 square meters in 1978. Moreover, a 1978 urban survey showed that per capita housing floor space was only 3.6 square meters. A special commentator's report in the People's Daily noted that the diversification of investment channels had contributed to excessive and uncontrolled accumulation in industry. Accordingly, adjustment of the rate of accumulation and the relationship between industry and agriculture could only be realized by consolidating central control over capital construction funds, the allocation of raw material and financial capital, that is, a partial reversal of reforms (Renmin Ribao 1980). The detrimental outcomes of uncoordinated accumulation bolstered the demands for recentralization by the more conservative leadership associated with the State Planning Commission. In February 1981, State Council declared that all investment in capital construction ought to be included within the government budget and was to be supervised by the Capital Construction Bank of China..$^{93}$ Additional measures were announced in spring 198 . The central state was to significantly expand its control over capital construction, banking and taxation, material supplies and pricing (Yao 1981). ${ }^{94}$ The extensive remit attributed to the central state was deemed necessary to deal with the rapid increase of extrabudgetary funds, which constituted a primary source of industrial investment. ${ }^{95}$ The consolidation of fiscal control indeed allowed the center to finally push forward

\section{Xinhua News (February 3, 1981).}

94 Yao Yilin had assumed the position of director of the State Planning Commission in March 1980.

95 In fact, fiscal control had already been significantly decentralized from the Great Leap Forward onward; from 1959 to 1978 , local government controlled an average 84.5 percent of state revenue. However, following the reforms, extrabudgetary revenues (over which 
the readjustments that had been a focal point of economic policy from 1978 onward. By the end of 1981, the output of agriculture and light industry had grown by 5.7 and 14.1 percent respectively. Heavy-industrial output, by contrast, had contracted by 4.7 percent. In tandem, the rate of GFCF was steadily decreasing.

The changing pattern of economic development was not, however, met with unequivocal approval. From the outset, Deng's policies of readjustment and reform had been opposed by conservative leaders and scholars. They remained of the opinion that economic development depended on the accelerated growth of the producer goods sector (Liu 1979). To support their argument, proponents of accelerated industrialization pointed out that the contraction of heavy industry had been accompanied by a decline in overall economic growth. ${ }^{96}$ While acknowledging the importance of agriculture, light industry and industry, economists like Zhou Shulian and Wu Jinglian reiterated the Maoist-era view that their development could only be realized through the manufacture of producer goods for these sectors (Zhou and Wu 1981). Further constraints on the rate of accumulation and the growth of heavy industry would result only in "recession and economic stagnation" (Liu, P. 1982, p. 29; Sun 1982). ${ }^{97}$ The development of industry was hampered not only by the renewed emphasis on agriculture, but also by the myriad fiscal measures introduced after 1979 to supplement household incomes. Subsidies on food, housing and welfare between 1979 and 1981 totaled 62.8 billion yuan or about 20 percent of state revenues realized in that same period. Increasingly, economists advocated that the growth of consumption would be kept below the rate of growth of GDP (Liang and Yang 1982). Dong Fureng, writing in Caimao Jingji (Finance \& Trade Economics) in April 1982, claimed that it was correct to stress the development of light industry and agriculture at present. However, in his opinion, "There is no doubt that the growth of light industry cannot be permanently higher than that of heavy industry and that the slowdown of heavy industry should not continue indefinitely" (Dong 1982, p. 12). His reasoning

the center exerted no control) rose rapidly, equaling $5^{1}$ percent of budgeted state income by 1981 (NBS 2005, table 23).

96 In 1981, the growth rate of GDP had fallen to 5.2 percent, 2.6 percent below the previous year (NBS 2005, table 8).

97 Others took an intermediate position. In their perspective, "reducing heavy industrial output is only a temporary measure, and allowing light industrial output to grow faster than heavy industrial output also must not be instituted as long-term policy" (Liu and Liren 1981, p. 7; see also Dong 1982). 
was that, in the long run, a high growth rate in light industry cannot be sustained without priority being given to the development of heavy industry. In Jingji Yanjiu, in May 1982, Sun Shangqing criticized the view of stressing, in a one-sided way, improvement of the people's standard of living and neglecting capital construction as being "erroneous in theory and harmful in practice." Although it had been necessary to improve the income level of the population "several years ago," it was impossible to realize such a large increase year after year because that would affect necessary capital construction. Consequently, the consumer goods sector should not always be assigned top priority: "During a certain period and under certain conditions heavy industry must be assigned priority in economic development" (Sun 1982). In sum, from late 1981 onward several of China's leading economists would increasingly question official readjustment policies. They were clearly worried about the downward trend of heavy-industrial production and what seemed to be too large increases in consumption levels with negative effects on necessary capital construction.

However, unanimous agreement was not reached. The October and November 1982 issues of Jingji Yanjiu carried articles arguing that agriculture was still the strategic pivotal point in economic development. Wang Songpei and Qiao Tongfeng stressed that overall economic growth depends on the agricultural surplus (surplus labor) supplied by the peasants after having fulfilled their own needs. They admitted that the modernization of agriculture requires the support of technical equipment from industry, but "in the final analysis the modernization of industry and industry's rapid development depend on a firm foundation of a rapidly developed agriculture" (Wang and Qiao 1982). Not surprisingly, they also favored "a speedy rise" in the income and standard of living of the people, especially the peasants. Zhang Zhouyuan claimed that in 1981, when heavy-industrial production dropped, "some people" overestimated the seriousness of the problem and "said that the national economy was withering" and "even set the development of heavy industry against that of agriculture and light industry just because readjustment over the past two years slowed down the growth rate of heavy industry, particularly in the machinebuilding industry" (Zhang 1982). Agriculture remained the foundation or rather "the primary strategic task" in economic development. As to the relationship between heavy industry and light industry, a strategy of making the rate of development of light industry surpass that of heavy industry should still be applied. In sum, although advocates of a rise in heavy-industrial production and increases in investment seemed to be in the majority, proponents of a development strategy stressing the strategic role of the consumer goods sector (light industry and agriculture) were by no means silenced. 


\section{The Sixth Five Year Plan (1981-1985): From Plan Economy to Macro-control}

Throughout $1982,{ }^{98}$ state leaders labored to devise a definitive strategy for economic development under the period of the Sixth Five Year Plan. In January, Chen Yun convened leading cadres within the State Planning Commission to discuss the appropriate roles of plan and market allocation. All parties agreed that China's economy ought to be regulated by some combination of central planning and market allocation. Devolution of fiscal and operational authority was believed to incentivize enterprise and improve responsiveness to local demand and supply conditions. However, the economic imbalances of the Great Leap, Cultural Revolution and the overaccumulation of the early 1980s, it was argued, constituted proof that overall departure from the principle of planning would be detrimental to economic development (Xiang, Zhang and Tian 1982). In defining the respective scope of plan and market, the majority insisted on adhering in principle to the boundaries first proposed by Chen Yun in 1956:

[T] he backbone enterprises [constituting] the national economic lifelines and major products must be included in national planning; ${ }^{99}$ the major proportions within the national economy must be strictly controlled through national planning[.] ${ }^{100}$ At the same time, we must fully utilize the supplementary instrument of market allocation; and the production and exchange of the many diverse commodities that are unsuitable for unified planning can - within the boundaries of the plan-be organized according to changes in market supply and demand.

GONG AND XU 1982, P. 8

An important framework for the debate at the time was Chen Yun's statement that the relationship between the market and the plan was similar to the relationship between a bird and a cage (Brødsgaard 1991). The plan is the cage and the market is the bird in the cage. According to Chen Yun, if the cage was too small or too tight, the bird could not move and would suffocate. But if there is no cage, the bird would fly away. In practice the bird was given more freedom

\footnotetext{
98 Although the plan nominally covered the period 1981 to 1985 , it wasn't in fact actually completed until December 1982.

99 The national economic lifelines (guojia jingji mingmai) are comprised of heavy industry, energy and transportation.

100 The major proportions were those between capital accumulation and consumption, agriculture and industry, and light and heavy industry; see $\mathrm{Su}(1982)$.
} 
than Chen Yun thought acceptable. According to Xue Muqiao (1982) effective simultaneous operation of planned and market allocation would hinge crucially on the utilization of "economic levers" (jingji ganggan), that is, indirect measures by which the state could influence supply and demand. The rationale for relying on economic levers was twofold. On the one hand, as the technical and ideological conditions of socialism were still far from complete, it was considered unfeasible to engage in comprehensive planning. On the other, without central guidance, decentralization would cause deviation from plan targets (Xiang, Zhang and Tian 1982). The primary economic lever comprised a system of disaggregated prices. Scarce or crucial economic inputs (e.g. energy and major producer goods) would be subject to fixed planned prices (guding jiage). Prices for certain major commodities would be allowed to float within a centrally stipulated minimum or maximum (fudong jiage). Certain agricultural products and output of TVEs would be priced on the basis of periodic contracts (yigou jixiao jiage). The price of remaining commodities would be determined on basis of market demand (jishi maoyi jiage), and would not be subject to any restrictions (Su 1982).

The use of price controls, it was argued, amounted to the conscious manipulation of the law of value in order to regulate supply and demand and maintain overall economic balance (Gong and Xu 1982). Accompanying fiscal measures were to ensure that price controls would not adversely affect enterprise performance: "[We] must ensure the coordination of price and fiscal allocation, and taxation in particular. If the prices of certain commodities are adjusted downward in order to promote consumption, this will cause enterprise profits to be low and will inhibit the motivation of the producer... Under these conditions, we can decrease [...] the rate of taxation and adjust the rate of profit of enterprise, and achieve the objectives of guiding both consumption and production" (ibid., p. 8). Additionally, state control over the major economic proportions would be further bolstered through credit and a procurement policy (Xue 1982).

In September 1982 General Secretary Hu Yaobang delivered a report to the twelfth Party congress. Although $\mathrm{Hu}$ was a devoted proponent of reform, the report adhered to the moderate program proposed by Chen Yun. The direct impetus for the structural reforms introduced in the document was given by the aim to quadruple (fan liang fan) China's industrial and agricultural output by the year 200o. The realization of this objective depended on a two-partite strategy, first to:

[A]im mainly at laying a solid foundation, accumulating strength and creating the necessary conditions; and in the second, usher in a new 
period of vigorous economic development. ${ }^{101}$ This is a major policy decision taken by the Central Committee.

HU 1982, P. 17

The initial stage of development in turn, consisted of two stages. Under the Sixth Five Year Plan, the strategy of readjustment, reform, consolidation and improvement would be maintained as the main policy line. During this period, the emphasis would be on reform of the administration of enterprise and central-local government relations, so as to secure sufficient state revenues for key projects-notably in energy, transport and infrastructureand remedy the "blind expansion" of industry that had occurred as a consequence of market reforms. ${ }^{102}$ Additionally — and in line with the recommendations of the State Planning Commission - the economy was to be regulated through a three-tiered system of mandatory (zhilingxing) and guidance planning (zhidaoxing), and market allocation (shichang tiaojie). Those producer goods and commodities allocated through mandatory planning would have fixed prices, and a relatively small number of consumption goods could be freely traded on the market. The majority of goods would be subject to guidance planning, and exchanged on the basis of negotiated or floating prices. In the subsequent Five Year Plan period (1986-1990) the emphasis would be on the improvement of the efficiency of production through a comprehensive project of "technological transformation" (jishu gaizao). The modernization of extant production capacity would eliminate the wasteful and inefficient pattern of production associated with the initial reforms and provide the conditions for a subsequent period of rapid economic expansion.

The proposal failed to resonate with more ardent proponents of reform. In his response to the report, the director of the Economic Research Institute of the Chinese Academy of Social Sciences, Liu Guoguang, argued that the regulation of production and exchange by centralized and mandatory plan would fail to incentivize enterprise, would promote wasteful production and

101 In fact, Hu's proposal was based on the "three-step" development strategy (san bu zou), first articulated by Deng in 1979. According to this framework, the two aforementioned stages would be followed by a third period, lasting until the middle of the 21st century, in which China would attain the status of a middle-income country.

102 In a surprising turn in discourse, $\mathrm{Hu}$ attributed the problems that had appeared under reform to "leftist" influences: "[T] he main causes for [the appalling waste in production, construction and circulation] are the 'Left' mistakes of the past, which resulted in blind proliferation of enterprises, an irrational economic structure, defective systems of economic administration and distribution, chaotic operation and management, and backward production techniques" (Hu 1982, p. 16). 
would erode the emphasis on product quality and diversity. Liu Guoguang charged that "the consequences of reduced microeconomic returns had gradually outweighed [centralized planning's] superiority in producing macroeconomic returns" (1982). Accordingly, the scope of planning ought to be further reduced in favor of additional market reforms. State leadership was, however, quick to repudiate Liu's criticisms. An official response in the People's Daily judged Liu's assertion that planning would induce poor microeconomic results to be unfounded. It, moreover, added that divergence from the leading role of the law of planned proportionate development would cause the economy to become governed by the spontaneous force of the market, and be harmful to both the interests of the people and the socialist cause (Anonymous 1982).103 In December 1982, the revised Constitution of the People's Republic of China (PRC) proclaimed "socialist public ownership of the means of production" the basis of its socialist system, the state economy "the leading force in the national economy" and "coordinated growth of the national economy through overall planning" the guiding principle. ${ }^{104}$

The Sixth Five Year Plan, promulgated in December 1982 amounted to a partial endorsement of Hu's proposals. The Plan stressed the need for increased fiscal centralization, stipulating that all investment in fixed capital—including that financed through extrabudgetary revenues - would be subject to approval by the State Planning Commission or its local branches, and all capital construction funds would be administered by the Construction Bank of China. ${ }^{105}$ It likewise dictated that from here on out, the expansion of industrial output was to be chiefly realized through "technological transformation" (jishu gaizao, i.e. modernization of extant production technology). ${ }^{106}$ While the plan thus ascribed a greater role to the central state, it omitted the emphasis on further sectoral readjustment. Instead, the plan rather unequivocally proposed the reinstatement of the strategy of accelerated accumulation. The projected rate of accumulation was adjusted upward to reach 29 percent by 1985. Although, in his address, Hu commented on the necessity of "taking agriculture at the basis," he likewise insisted that:

103 Given this strong condemnation of Liu's article, one could wonder why it was allowed to be published in the first place. A plausible explanation is that Liu's criticisms reflected the opinions of Hu Yaobang, who, however, had to refrain from proposing a more radical course of reform because of the need to maintain political coherence.

104 Constitution of the P.R.C., December 4, 1982, articles 6, 7, 15.

105 "Guomin jingji he shehui fazhan di liu ge wu nian jihua (tiyao)" (1982).

106 Ibid., ch. 1. 
[L]iving standards can increase only by increasing production, and not by cutting into funds indispensable to national construction[.] Specifically, we can no longer increase peasant incomes through raising the prices of farm produce or through lowering the fixed quotas of state purchases and enlarging the scope of negotiated prices.

1982, P. 17

Notably, support for a more balanced trajectory of growth was not reiterated in the final iteration of the Five Year Plan, and, both within policy and academia, the emphasis on accelerated accumulation under intensified central control prevailed. As a consequence of the renewed emphasis on accelerated industrialization the more balanced strategy of economic development that had emerged in the late 1970 s and early 1980 s was once again overturned.

Although Hu's address to the twelfth Party congress had stressed the need to pair central control with the reorganization of enterprise administration, reforms within public industry unfolded at a slow pace. Arguably to prevent overaccumulation or duplication of investments in non-priority sectors, further enterprise reforms were omitted from the Sixth Year Plan. The financial and operational authority given to enterprise under the "eight rights" policy of 1980 had been partially revoked in favor of an elaborate, multitiered administrative system that stipulated production targets, tasks and corresponding remuneration. In 1983, the project of enterprise reform revolved around the trial implementation of a new corporate taxation system. Under the new tax regulations, enterprise transfers to central government would be comprised of a fixed proportion of profits, as well as a negotiated remittance. ${ }^{107}$ The policy was intended both to increase the financial prowess of the center as well as to offset any arbitrary interfirm differences in profitability owing to external factors, and irrational prices in particular (Zhang 1984). The limited progress under the Sixth Five Year Plan was decried by advocates of reform, who considered the measures taken by the state to be insufficient to incentivize enterprise (Xue 1994).

In 1982, the Office for Reform of the National Economic System (guojia jingji tizhi gaige bangongshi) was elevated to the position of commission directly under the State Council. In early 1984, the commission started work on the "Decision on Reform of the Economic System." The policy, officially adopted during the third plenary session of the twelfth Party congress in October 1984, called for a reform of every aspect of the entire economic structure. This involved a whole range of reforms, including planning, pricing, economic

107 "Guanyu guoying qiyeli gaishui shixing banfa" (1983). 
management, and the labor and wage system. The majority of these reforms were to be accomplished within five years. The goal was to make the individual enterprise an independent economic entity responsible for its own profits and losses, and able to act as a legal person with certain rights and duties.

The Decision claimed that in the reform of the planning system "it is necessary, first of all, to discard the traditional idea of pitting the planned economy against the commodity economy." ${ }^{108}$ In fact, according to the Decision, a socialist economy is a "planned commodity economy," and the difference between socialist and capitalist economy does not lie in whether commodity economy and the law of value are still functioning, but in the difference in ownership. In short, it is public ownership of the major means of production which defines a socialist system, not the structure of the planning system. The implication was that it is possible to attempt far-reaching reforms of the planning system without altering the fact that China is a socialist country.

The Decision likewise emphasized the need to address the problem of irrational planned prices. This included inadequate price differentials for a given product with varying quality, irrational price ratios between different commodities, particularly low prices for some mineral products and raw and semifinished materials; and the retail price of major farm and sideline products being lower than their state purchasing price. The Decision admitted that this situation constituted an obstacle to the reform of the planning system: "Therefore, reform of the price system is the key to the reform of the entire economic structure" (Guanyu tizhi gaige de jueding 1984). The Decision recommended a three-tiered pricing system to reflect and also support the tripartite management system: planned prices for essential products covered by the state plan, floating or negotiated prices for products under guidance planning, and free prices for products circulated in the free market.

Suggestions to pay more attention to what the Chinese call economic levers (pricing, taxation, credit etc.) were combined with suggestions to implement a wage and labor reform "in accordance with the principle of linking wages with responsibilities and achievements" so as to reflect more fully "the differences between mental and manual, complex and simple, skilled and unskilled, and heavy and light work" (ibid.). Along these lines there was also a call for an enterprise management system where the director or manager assumes

108 "Guanyu jingji tizhi gaige de jueding" (1984). This phrase was the subject of a large number of articles in the fall and winter of 1984. See, for example, Guangming Ribao on December 9 and December 10, 1984, and Jingji Ribao on November 19 and 21, 1984. See also the article by Liu Guoguang who by now had become vice-president of the Chinese Academy of Social Sciences (Liu 1984). 
full responsibility. The Decision pointed out that a thorough reform of the economic structure required a contingent of managerial and administrative personnel, and especially managers knowledgeable in modern economics and technology. It was therefore considered necessary to promote a new generation of managerial personnel. This was called "reshuffling of leadership in enterprises," and was to be completed before the end of 1985. The "Decision on Reform of the Economic Structure" was given wide coverage in the media in China as well as abroad. The Chinese used phrases like "great practical importance" and "far-reaching historical significance" in order to emphasize that this time the reform process did not aim at partial and minor alterations of the system, but rather had entered a stage of "comprehensive reform."

Following the promulgation of the Decision, the number of industrial products regulated by the mandatory plan was reduced from 120 to 6o; centrally controlled agricultural production was limited to 10 commodities (previously 29); and the variety of centrally distributed materials was scaled back from 256 to 65 (Song 1985). ${ }^{109}$ Further adjustments to the price system were made the following year. In March 1985 the Central Committee issued a circular (zhongfa) which consolidated the shift from planning to market regulation in farm production. State purchasing quotas were to be abolished, and instead the state would buy grain and cotton according to contracts and allow farmers to sell their surplus production in the open market. Other agricultural goods were allowed to float at free market prices (Brødsgaard 1991). In May 1985, the state introduced the dual-track system (shuangguizhi). Enterprises producing goods under the mandatory section of the economic plan would enjoy state-stipulated reduced prices for key inputs such as coal and steel. Other enterprises would purchase materials on the market. ${ }^{110}$ As in the late 1970s, the reforms invigorated the economy, resulting in rapid growth throughout 1985 . However, as before, the upturn in industrial production brought on the alltoo-familiar problems of overaccumulation and reduced central fiscal control.

Moreover, devolution of financial control and rising wages resulted in an upsurge of demand for investment and consumer goods, causing inflation to reach 9.3 percent. In the era of economic planning, the state had retained control over funds and production quota, and consequently, prices had only fluctuated by a narrow margin. This is not to say that under the Maoist system demand had not at times gravely surpassed supply. On the contrary, the persistent prioritization of industrial expansion had resulted in a chronic shortage of consumer products (see Zwass and Westphal 1978). However, with the

109 Also, Beijing Xinhua (1984, pp. 31-32).

110 "Guanyu jin yi bu kuangda guoying gongye qiye zizhuquan de zanxing guiding" (1984). 
introduction and rapid expansion of the market economy, such imbalances translated for the first time into periods of high inflation. Although absent in the planned economy, inflation did not altogether fall outside the scope of socialist economic analysis. Marx had dealt with the causes of inflation in his first volume of Capital.

According to Marx, changes in general price levels-expressed through the medium of money-are caused either by a change in the general value of commodities, or a change in the value of the money commodity. Marx provided various reasons why the value of the money commodity (as opposed to its denominational value, i.e. the amount of money units assigned to notes and coins) can change, but only one is relevant to the explanation of inflation in modern capitalist systems. When the volume of money in circulation is increased absent a commensurate increase in aggregate demand (i.e. the societal need for labor and capital), the exchange ratio between the money commodity and goods is altered, so that goods now trade for a greater increment of money, that is, a higher price (Marx 1990, ch. 3). While Marx considered inflation to be an intrinsic and unavoidable element of capitalism, his diagnosis acquiesced with central elements of monetary explanations. Accordingly, when increasing international academic exchange exposed Chinese economists to monetary and Keynesian theories, ${ }^{111}$ these ideas rapidly permeated into the Chinese economic discourse. Economists such as Liu Guangdi of the Central Research Institute for Public Finance insisted that control of the money supply was crucial to regulating production and ensuring price stability. Through the joint use of monetary and fiscal instruments such as interest rate and credit control, taxation and subsidies, the state would be able to either stimulate production or reduce inflationary pressure. Excessive increases of the money supply (utilized, for example, as a means of reducing unemployment or balancing national trade accounts), causing large deviations from aggregate demand were to be avoided (Liu 1985b).

Liu Guoguang reiterated the unsuitability of Keynesian policy, arguing that "considering the generally excited state of socialist economies, increases in the monetary supply can only exacerbate the level of economic anxiety" (Liu $1985 \mathrm{a}$, p. 14). From the latter half of the 1980 os onward, monetary policy became a staple of economic governance. In January 1985, the State Council had begun

111 For example, following central concerns about economic instability, the Chinese Academy of Social Sciences and the Research Unit for Economic System Reform jointly hosted a conference on macroeconomic management in September 1985. The conference was attended by economists both from Eastern European transition and capitalist economies. 
to convert funds earmarked for the expansion of enterprises' fixed assets into interest-bearing loans. The central state increasingly relied on the manipulation of interest rates to discipline soes and reduce inflationary pressures. However, Liu Guoguang forewarned that under conditions of pervasive soft budget constraints-wherein the state continued to bear ultimate responsibility for firm expenditures - managers would prove insensitive to the effect of changes in the interest rate on the financial performance of enterprise (ibid.). Indeed, the efficacy of monetary and fiscal policy under Zhao Ziyang and $\mathrm{Hu}$ Yaobang continued to be marred by the obstacles of incomplete reforms.

\section{Price and Ownership Reform, Inflation and the Origins of the Tiananmen Incident}

However, in spite of the reemergence of macroeconomic imbalances in 1985 , $\mathrm{Hu}$ Yaobang and Zhao Ziyang were determined to sustain the momentum of reform. The decision to accelerate reform caused disagreement among senior leadership, bringing an end to the alliance of Chen Yun and Deng Xiaoping that had ushered in the first phase of reforms. Discussing the initial draft of the Seventh Five Year Plan at the national convention of the CCP on September 23, 1985, Chen Yun proved strongly critical of initial proposals (Naughton 2009). According to Chen Yun, agricultural reforms had induced farmers to focus on the production of cash crops and neglect grain cultivation, while decentralization within industry had brought about runaway growth and overaccumulation. Moreover, the receding influence of the central state and expansion of the market had provided the incentives and opportunities for corruption, causing popular dissatisfaction. The resolution of these problems, argued Chen, depended on maintaining the maxim of upholding the planned economy as the main element and the market economy as a complement, and renewing the emphasis on ideological education (Chen 1986). However, in an address given that same day, Deng expressed his unwavering support for the reforms, stating that the achievements within the subsequent Five Year Plan period would prove crucial to the success of the overall strategy of quadrupling China's economic output by the year 2000. Moreover, Deng added that it was inevitable that these comprehensive changes would be paired with a certain amount of disparity between individuals and regions, but that ultimately the economic invigoration resulting from reforms would benefit all (Deng 1985).

Despite the objections of more conservative leadership, the prevailing sentiment during the years leading up to and following the promulgation of the new Plan was that the scope and pace of reforms ought to be increased. How- 
ever, policymakers and academics were not insensitive to the contradictions that had appeared in the preceding years. Gradually, the debate on economic reform shifted away from the initial doctrinaire perspectives, wherein the law of planned proportionate development, macroeconomic balance and centralized control were juxtaposed against the law of value, microeconomic performance and decentralization. Instead, a consensus that the objective of reforms was to bring about and maintain simultaneous microeconomic equilibrium and macroeconomic stability formed. Due to the easing of ideological constraints and greater foreign academic exchange, academics could now draw on Western economic theories too. Jointly, the influx of novel ideas and methods and the ostensible incapability of the extant paradigm to provide an adequate response to the problems accompanying China's economic development caused discourse to gradually depart from the narrow socialist analysis of sectoral proportions. One major consequence of this development was the emergence of the concept of rationality in economic discourse. ${ }^{12}$ According to China's leading economists, the imbalances that had periodically appeared were due to the partial and erratic manner in which reforms had been carried out. As a result, irrationalities had cropped up both within the management of enterprise and economic governance.

A first problem was caused by enterprises' concurrent pursuit of the maximization of output and employment, prompting the reckless expansion of productive capacity. Such behavior was encouraged by the state's patronage of poorly performing enterprise. Because the allocation of credit was still largely determined on basis of production quota, the correlation between investment and profitability was obscured, causing management to ignore the rate of return on capital ( $\mathrm{Hu}$ and $\mathrm{Lu}$ 1986; Liu 1987). Rather, enterprise managers used bank credit to expand production and employment or increase wages. ${ }^{113}$ Additionally, Party secretaries had retained de facto ultimate authority over the management of enterprise, and regularly interjected objectives that detracted from management's pursuit of profits.

112 Different definitions of rationality were put forward. One conception considered rational behavior to entail rapid adjustment to prevailing conditions of plan or market, and the steady expansion of productive accumulation; a second view reiterated the classical position that the rational enterprise, by engaging in the pursuit of profit, would promote the maximization of public utility; a third emphasized the removal of internal and external inefficiencies to be the essence of rational economic behavior, see Liu (1987).

113 Although not explicitly referenced, this argument clearly draws on the theory of principal-agent problems put forward by Berle and Means (1965). 
Solutions to the problems of irrational enterprise behavior differed. The separation of ownership and management rights was widely proscribed. Because, under soft budget constraints, economic efficiency was inconsequential to the operation of enterprise, management habitually engaged in loss-inducing practices (Zhou, Liu and Zhang 1986). Moreover, enterprises had been shielded from competition by protectionist policies issued by industrial ministries and local government. Xue Muqiao argued that through the introduction of the managerial responsibility system (jingli zerenzhi), the influence of Party organs within enterprise would be scaled back, and management would be held solely accountable for firm performance. The state, as owner of the enterprise, would retain the right to appoint and dismiss management (Xue 1987). The separation of state and enterprise (zhengqifenkai) was considered crucial in bringing an end to the soft budget constraint within public industry. Others went further still, arguing for changes to the ownership system itself. By implementing joint stock ownership, enterprise assets would be shared between the state and management and employees, ensuring both parties' interest in the financial performance of the firm (Li 1986).

Problems at the level of enterprise were compounded by irrationalities in pricing and fiscal policy. The arbitrary application of "adjustment taxes" following the debate on irrational disparities in enterprise profitability had resulted in a situation where enterprises with above-average financial performance ended up remitting a disproportionate proportion of revenues to the state (Yue and Yue 1987). A group of economists maintained that because of this phenomenon of "whipping the fast ox," firms were disincentivized to increase productivity (Zhou, Liu and Zhang 1986). Others emphasized price reforms. Thus, Zhou Shulian (1986) held that, regardless of the transfer of financial and operational authority to enterprise, the relationship between productivity and performance would continue to be distorted absent the comprehensive liberalization of factor prices (including raw materials, technology and labor). Within the first phase of reform, the central state had relied chiefly on price controls to ensure that sectoral development and supply and demand accorded with macroeconomic objectives. The development of a dual-track pricing system, in which planned and market prices widely diverged, provided soes ample opportunities for engaging in arbitrage by selling material procured at reduced prices on the free market. Accordingly, Dai Yuanchen of the Chinese Academy of Social Sciences advocated the abolishment of the two-track pricing system (Dai 1986). This did not imply that the state should completely relinquish its control over prices; government intervention in pricing was still deemed necessary in order to alleviate inflationary pressures and remedy instances of insufficient market supply. However, both the scope of state- 
controlled prices, and their divergence from market prices, was to be gradually reduced (Li 1987).

While the diagnosis of the general obstacles to rationalization of the economic system was widely shared, a division developed between those arguing for an emphasis on completing the transfer of fiscal and operational responsibility to enterprise, and those prioritizing adjustment of the price system (Hsu 1989; Naughton 2009). The former believed that without first completing the separation between state and enterprise, further price liberalization would prompt price appreciation and cause overinvestment. The latter argued that enterprises could not be induced to function competitively without first removing regulatory rents and opportunities for arbitrage.

The outline of the Seventh Five Year Plan, published on September 4, 1986, reflected the accelerated momentum of reforms. The plan's relatively modest economic targets ${ }^{114}$ reiterated the notion that reforms would require restructuring at the level of enterprise, ${ }^{115}$ which would temporarily reduce the growth rate of output. Nevertheless, so as to minimize the disruptive influence of reform and prevent economic stagnation, credit and infrastructural funds were increased by a large margin. ${ }^{116}$ In order to resolve bottlenecks in upstream sectors, a greater proportion of investment would be allotted to the development of raw materials' extraction and processing, transport, energy and telecommunications. Expenditure for the technological transformation of enterprise would also be increased by a margin of 80 percent, compared to the previous Five Year Plan period.

Under this basic framework, the strategy for reform under the Seventh Five Year Plan would unfold in two stages. Within the first two years, the financial and operational independence of enterprise would be established. ${ }^{117}$ All enterprises would be subject to the managerial responsibility system. Moreover, a large number of small or medium-sized soEs would be transformed into collective or private enterprises. In the latter three years, policy would focus on market reforms, by promoting the further substitution of indirect for direct controls. After the completion of the devolvement of fiscal responsibility, the state would also be able to continue with the adjustment of the taxation

114 The plan proposed an average annual growth rate of GDP of 7.5 percent, compared to the 10.8 percent realized during the Sixth Five Year Plan.

115 First put forward in the two-stage strategy of quadrupling China's GDP by 2000.

116 Funds for investment in fixed capital under the Seventh Five Year Plan would total Rмв 81.96 billion, compared to outlays of 36 billion in the Sixth Five Year Plan.

117 "Guomin jingji he shehui fazhan diqi ge wu nian jihua (zhaiyao)" (1986). 
system so as to eliminate arbitrary discrepancies in the financial conditions of enterprise.

Following the promulgation of the plan, the State Council went ahead with a full-scale implementation of the managerial responsibility system. ${ }^{118}$ The system would provide management with the authority to engage in the drafting of the enterprise's operational plans, and the Party committee would be relegated to a supervisory status. Additionally, the center sought to dilute the corporate control of industrial ministries and provincial government through the development of horizontal linkages (hengxiang lianhe) between enterprises. By creating large diversified enterprise groups that operated at a national scale, industrial or provincial bureaus would no longer be able to unilaterally dictate their operational remit. ${ }^{119}$ Subsequently, policies were introduced to separate state and enterprise finance. The "Enterprise Bankruptcy Law", introduced on a trial basis in December 1986 further advanced the objective of financially independent enterprise. The following year, the scope of the contract responsibility system (chengbao jingying zerenzhi) — which the state had begun to experiment with from 1983 - was expanded, further increasing managerial autonomy. ${ }^{120}$ The state's influence over enterprise finance was nominally limited to the taxation of profits and contractual stipulation of targets for technological transformation. By linking enterprise wage expenditure directly to profits, the state sought to put an end to the indiscriminate expansion of wages and employment (Yue and Yue 1987).

Despite their fairly comprehensive scope, policies introduced in 1986 and 1987 failed to truly instill greater economic discipline within enterprise. Although the measures nominally acquitted the state from the financial responsibility for enterprise, the soft budget constraint remained intact. No progress was made with the collectivization or privatization of enterprise. Although the relaxation of ideological constraints had allowed for the transformation of the relations of production, public ownership of the means of production-enshrined in the 1982 Constitution - was considered the sine qua non of socialism. For the same reason, the Bankruptcy Law failed to have any significant influence, and the number of soes continued to grow (NBS 2005, table 41). Incomplete regulation further contributed to the continuation of non-productive practices. Although, under the contract responsibility system,

118 "Guowuyuan jueding jin yi bu shixing changzhang fuzezhi fenfa san ge tiaolie de tongzhi" (1986).

119 "Guanyu jin yi bu tuidong hengxiang jingji lianhe ruogan wenti de guiding” (1986).

120 The contract responsibility system was subsequently enshrined in the Enterprise Law of 1988. 
enterprise loans were no longer explicitly guaranteed by the state, enterprises were not legally obliged to repay their debts to banks. Moreover, the state continued to be financially accountable for interest payments, because these were included in expenses and subtracted from profit remittances to central government (Bowles and White 1989). Because banks lacked the capacity to closely monitor enterprise performance and were under pressure to allocate credit in accordance with central plans, indiscriminate lending to poorly performing enterprises continued.

Popular unrest, incited by demands for political reform and rapidly increasing inflation weakened the support for reforms amongst central leaders. A series of consequential personnel changes occurred within the Party and state throughout 1987. Senior leaders Deng Xiaoping and Chen Yun retired from the CCP's Politburo Standing Committee (zhengzhiju changwei), China's de facto most powerful policy body. ${ }^{121}$ Among the four new members introduced, $\mathrm{Hu}$ Qili was the most ardent proponent of reform. Yao Yilin (head of the State Planning Commission) and Li Peng (who took on the position of premier vacated by Zhao) both supported the conservative Chen Yun, while Qiao Shi took a more ambiguous position. Earlier, in January of that year, Hu Yaobang had been relieved from his position as Party general secretary—allegedly over disagreements with Deng concerning succession and the course of political reforms (Dietrich 1998). Nevertheless, under the patronage of Deng, Zhao Ziyang — who had taken over Hu's post of general secretary — was still able to direct the course of economic policymaking, in spite of criticism from Chen Yun and the conservatives.

Thus, despite the questionable efficacy of enterprise reorganization and objections from conservative leaders, the state persisted with the measures set out in the Seventh Five Year Plan. At the thirteenth National congress, in October 1987, the theory of the "primary stage of socialism" was formally endorsed by the $\mathrm{CCP}$, providing the ideological justification for further departure from the model of the plan economy. In February of the following year, the State Commission for Economic Restructuring (guojia jingji tizhi gaige weiyuanhui) published an extensive outline for further enterprise and market reforms. The plans were followed by the announcement of further price liberalization by Zhao and Deng in August of $1988 .{ }^{122}$ With inflation already growing at an alarming rate, public expectations of further price increases caused panic buying and led to severe shortages.

\footnotetext{
121 Deng, however, retained his title as chair of the Central Military Position and remained de facto paramount leader.

122 "Guanyu jiage, gongzi gaige chubu fangan" (1988).
} 
The economic turmoil stopped reform dead in its tracks. Although Zhao maintained his position as general secretary, control of economic policy was promptly transferred to Li Peng and Yao Yilin. In response to the mounting economic problems, $\mathrm{Li}$ and Yao followed the conservative mantra of recentralization and retrenchment. ${ }^{123}$ While nominally insisting on the importance of reform, the new economic leadership quickly proceeded to reinstate price controls, reduce the money supply and halt fixed asset investment outside of the plan. ${ }^{124}$ The measures, however, proved ineffective in restraining inflation and unsustainable as they caused supply to decrease at a faster rate than demand. ${ }^{125}$ Moreover, the restricted flow of credit to enterprise affected wages. The growing discontent of urban workers coalesced with students' and intellectuals' increasing demands for political reforms, setting the stage for the Tiananmen protests, which would culminate in the tragic events of June $4 \cdot{ }^{126}$

\section{Tiananmen and the Reemergence of Conservatism}

The economic and political consequences of the Tiananmen incident were profound. Whereas the general trend prior to the incident had been toward the retrenchment of government, central control now became the overriding imperative. Zhao Ziyang, who had proved sympathetic to the demands of the student protesters and intellectuals, had been ousted two weeks before the Tiananmen military crackdown on June 4, 1989. The position of Party secretary was given to Jiang Zemin, who had previously served as Party leader in Shanghai. The appointment of Jiang — who was politically conservative but

123 Reflecting on political developments in the 1988, Zhao stated: "When 'adjustment and reorganization' began, [Li Peng and Yao Yilin] believed that my position in economic affairs had weakened. They took controlling power, which meant the Politburo Standing Committee, the Central Economic and Financial Leading Group, and I could no longer run economic affairs. Thus they were able to restore many of the old methods, in the name of 'adjustment and reorganization'" (Zhao 2009, pp. 233-234).

124 "Guanyu zuo hao dangqian wujia gongzuo he wending shichang de jinji tongzhi" (1988). "Guanyu qingli guding zichan touzi zai jian xiangmu, yasuo touzi guimo tiaozheng touzi jiegou de tongzhi” (1988).

125 Due to the persisting soft budget constraint, enterprises tended to lower output when credit contracted, withholding retained profits to reinvest in the expansion of production and wages at a later point, see Naughton (1996, pp. 266-268).

126 For an account of the pro-democracy protests and military crackdown, see Beja (2010), on intra-Party debates surrounding the handling of the Tiananmen incident, see Nathan (2001) and Zhao (2009). 
had proven sympathetic to reform-was ostensibly a compromise between Deng Xiaoping and Chen Yun.

However, coming from relative political obscurity, Jiang's political influence was limited. With the removal of Zhao and most of the reformists, Li Peng was now in unambiguous control of economic policy. Initiatives to transfer financial authority to enterprise were halted altogether. The rapid proliferation of state-owned and collective industry under decentralization had precipitated excessive demand for investment, caused shortages in agriculture and upstream sectors, and severely weakened the center's fiscal control. In the following years, leadership reverted to the traditional credo of consolidation and adjustment. The former authority of the Party committees within enterprise was reinstated. ${ }^{127}$ In tandem, central leadership sought to extend its control over credit allocation, basic construction funds and pricing. The scale of capital investment was to be scaled back by a large margin, and a larger proportion would be allocated to heavy industry and agriculture. The dual-track pricing system was to be retracted to return to a system of more elaborate direct price management (Perkins 1990). ${ }^{128}$

Significant reductions in the supply of credit and funds for capital construction in 1989 and 1990 slowed down the expansion of industry, while limited wage increases constrained consumption. The fiscal measures were accompanied by high interest rates (promoting a rapid increase of deposits) and a contraction of newly issued currency. Jointly, these measures were successful in slowing down accumulation and curbing inflation. Between 1989 and 1990, total investment in fixed assets went from 25.4 percent growth to actually decreasing by some 7.8 percent. Simultaneously, the consumer price index dropped from 118.0 to 103.1 (NBS 1999, table 9-1).

Nevertheless, the conservative leadership, considering inflation but a symptom of more fundamental structural imbalances, sought to further increase its control over economic activity. The Eighth Five Year Plan introduced further measures to centralize the allocation of credit and investment funds, so as to promote the development of upstream sectors (and energy in particular), which were believed to have been neglected as a result of market reforms. Investment in agriculture too was to be increased, but responsibility was delegated to local government and TVEs. ${ }^{129}$ The renewed emphasis on heavy industry was in part motivated by a desire to boost profits appropriable from

\footnotetext{
127 "Guanyu jin yi bu gao hao qingli zhengdun gongsi gongzuo de si tiao cuoshi" (1989).

128 "Guanyu jin yi bu zhili zhengdun he shenhua gaige de jueding" (1989).

129 "Zhonghua renmin gongheguo guomin jingji he shehui fazhan shi nian guihua he di ba ge wu nian jihua gangyao" (1991).
} 
centrally controlled enterprises, and counter the progressive decline of central revenues. However, the policies introduced by Li had severely constrained the profitability of soEs operating within heavy industry. Price controls on industrial inputs and reduced downstream demand had squeezed revenues, while the costs of fixed capital had increased (Naughton 1996, ch. 8). Nor had the detrimental consequences of contractionary measures been limited to upstream industry. In 1989, overall economic growth had plummeted to 3.8 percent, and, at 4.1 percent in 1990, prospects for economic revival seemed bleak. Indeed, voices calling for the continuation of reforms started to increase in 1991, and in January 1992, Deng Xiaoping made a series of appearances in several southern provinces that, though informal, proved highly instrumental in rekindling the enthusiasm for decentralization and marketization. To Deng, the Tiananmen incident was not about economic reform, but about political power and control. He was convinced that once political control had been restored, the economic reform process had to be resumed. During his "southern inspection tour" (nan xun), Deng emphasized that those in central leadership who were opposed to reform must step down (Vogel 2011, pp. 669-69o). Jiang Zemin and the new leadership realized they could not ignore this threat by Deng, who still held tremendous sway within the Party, and they accordingly abandoned their austerity policies in favor of renewed reform.

However, in the subsequent period, reforms would be of a fundamentally different character. Periodic reversions to the principles of centralized allocation and the limitation of managerial autonomy had led the leadership to believe that comprehensive planning would induce poor microeconomic results and slow down growth. However, the inflation that had accompanied unbridled decentralization had likewise espoused a conviction — strengthened by the social instability of the late 1980 - - that strong central macroeconomic control would be indispensable.

\section{Economic Developments in the First Phase of Reform}

The initial impetus to reform was provided by severe intersectoral imbalances that had resulted in the stagnation of the overall economy and agriculture in particular. In the period of the Cultural Revolution (1966-1976), economic growth had decreased to an average 5.9 percent, while growth in agriculture had plummeted to 2.8 percent. In the first period of reforms (1978-1992), the rate of overall economic growth had climbed to an impressive average 9.6 percent; agriculture too had achieved steady growth at 5.2 percent (NBS 2005, table 8). Initial reforms focused on sectoral readjustment by putting an end to the strategy of agricultural expropriation. The development of a 
TABLE 5 Average annual growth rates of agriculture, 1952-1984

\begin{tabular}{|c|c|c|}
\hline Subsector & $195^{2-1978}$ & $197^{8}-1984$ \\
\hline Crops & 2.5 & $5 \cdot 9$ \\
\hline Grain & 2.4 & 4.8 \\
\hline Cotton & 2.0 & $17 \cdot 7$ \\
\hline Animal husbandry & 4.0 & 10.0 \\
\hline Fishery & $19 \cdot 9$ & 12.7 \\
\hline Forestry & $9 \cdot 4$ & 14.9 \\
\hline Agriculture (total) & 2.9 & $7 \cdot 7$ \\
\hline
\end{tabular}

SOURCE: LIN (1992, P. 35).

supplementary market for produce prompted farmers to shift production toward cash crops and livestock, which fetched higher prices.

The rural economy was further invigorated by the rapid proliferation of TVEs. Fueled by idle rural labor, local state investment and strong demand for consumer goods, employment in TVEs increased from 28.3 to 92.6 million, and output surged from 49.3 to 958.1 billion RM B between 1978 and 1990. ${ }^{130}$ Public industry likewise continued to grow at a rapid rate. soes in heavy industry had remained the focal point of economic planning and continued to receive the lion's share of centrally allocated funds and credit. Moreover, increased production of consumption goods had led to an increase in demand for machinery and raw materials (Pei 2005). Although the development of industry was temporarily decelerated by the suspension of planned investments in 1981, policy continued to reflect a perspective that equated economic growth with industrial development, and overall, the growth of industry continued to outpace that of agriculture. The expansion of industry in turn drove the rapid development of trade and retail services, particularly after 1984, when the scope of planned material allocation was significantly reduced in favor of market exchange. Although national policy had emphasized the development of industrial infrastructure, the telecommunication and transportation sectors grew but moderately. ${ }^{131}$ All in all, the objective of sectoral readjustment, first formulated in the late 1950s, was not realized, and economic growth continued to be driven primarily by accumulation within industry (see Figure 5).

130 For comparison, agricultural output in 1990 totaled 766.2 billion.

131 The energy sector, on the other hand, developed rapidly during the first phase of reforms. 


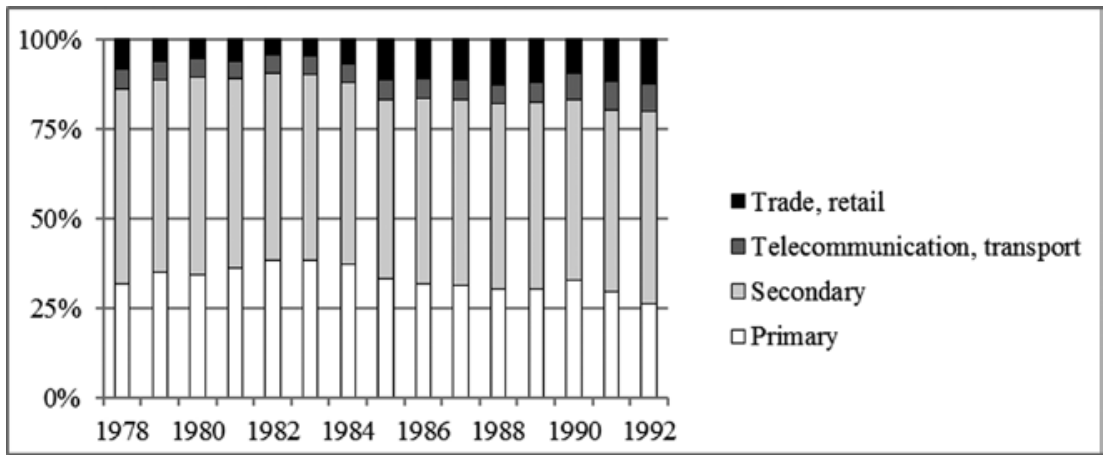

FIGURE 5 Sectoral composition of GDP, 1978-1992.

The failure of the readjustment strategy can be ascribed to its inherent incompatibility with reforms. Within the Maoist system of economic planning, sectoral adjustments had been achieved by way of changes in central allocation. However, the transfer of financial authority from the state to enterprise - central to attempts to improve productivity - had led to a weakening of the state. Between 1978 and 1992, state revenue decreased from 31.2 to 13.1 percent of GDP. Accordingly, the central state's capacity to directly influence the sectoral composition of the economy was severely curtailed.

Nevertheless, the comparatively limited growth of agriculture did not bring about the severe shortages that periodically emerged in the Maoist era. Although conservatives had continued to criticize the neglect of agriculture and staple crops in particular, efficiency in grain production had increased. ${ }^{132}$ Moreover, China's progressive integration into the world economy allowed it to compensate for shortfalls in the domestic harvest through international trade (Perkins 1990). At the same time, the transfer of agricultural labor to light industry through the establishment of TVEs had invigorated the rural economy and caused the gap between rural and urban incomes to narrow. ${ }^{133}$ While subsequent plans would continue to emphasize the development of the agricultural economy, concerns over the livelihood of the rural population would take precedence over issues of food security.

Although reforms had successfully dealt with the stagnating production and acute shortages within agriculture, it also gave rise to novel economic

132 In 1992, per capita output of grain was 19.3 percent higher than that of 1978, the largest harvest recorded prior to agricultural reforms.

133 Note that, following the austerity measures of 1986, and again in 1989, the divergence between urban and rural incomes widened again (Huang 2008). 
problems. The devolution of control over fiscal allocation to enterprise and local government promoted rapid economic growth, but also resulted in an upsurge of demand for credit, which could only be accommodated through an increase in the supply of currency. Most inflationary pressure was attributable to soe. Not only were soes the main recipients of bank credit, but soft budget constraints caused enterprise management to be inattentive to productivity. Loans made to soEs were habitually used to finance wage increases, which exacerbated inflationary pressures. Because of the excessive demand for investment and consumer goods, periods of decentralization were consistently characterized by the concurrence of rapid growth and inflation. While monetary measures were utilized in attempts to indirectly manage demand, such interventions had but a limited effect. Although high interest rates tempered panic buying and reduced currency in circulation, industrial demand for credit remained high. The state periodically reverted to the centralization of control over credit, but ideological and political constraints limited the scope of adjustments within public industry. Rather, contractions in credit supply predominantly affected TVEs, which were the primary drivers of economic growth. As a result, economic growth in the first era of reforms was characterized by the alternation of periods of high growth and inflation during decentralization, and periods of economic stagnation under recentralization (see Figure 6).

Not only did public industry's incessant demand for capital contribute to periodical inflation, but it caused structural imbalances that increasingly undermined the viability of Chinese economic development. Measures to devolve financial and operational authority had not been able to ensure the efficient operation of soEs. Because the state continued to rely on public

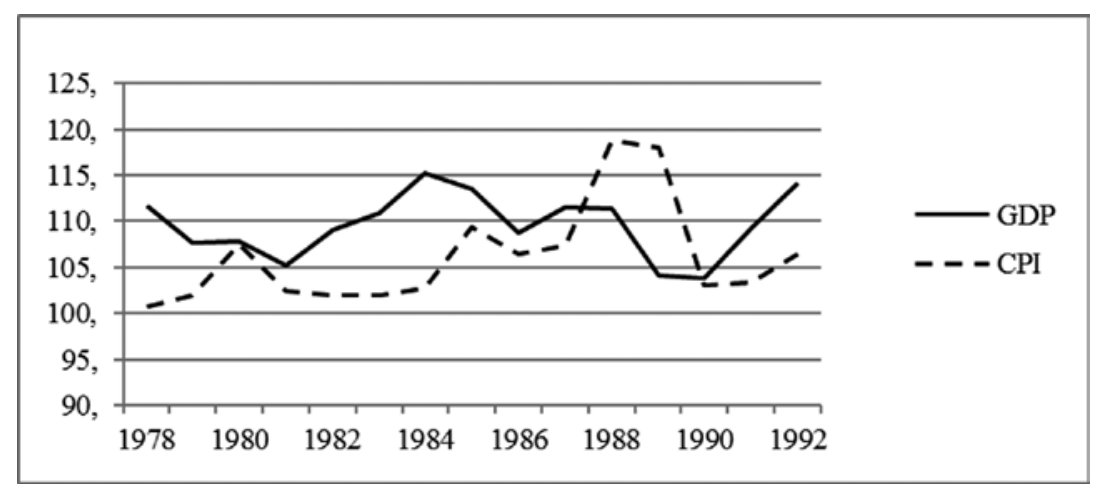

FIGURE 6 GDP growth and inflation, 1978-1992 (percentage change over previous year). SOURCE: NBS (2005, TABLES 6, 29). 


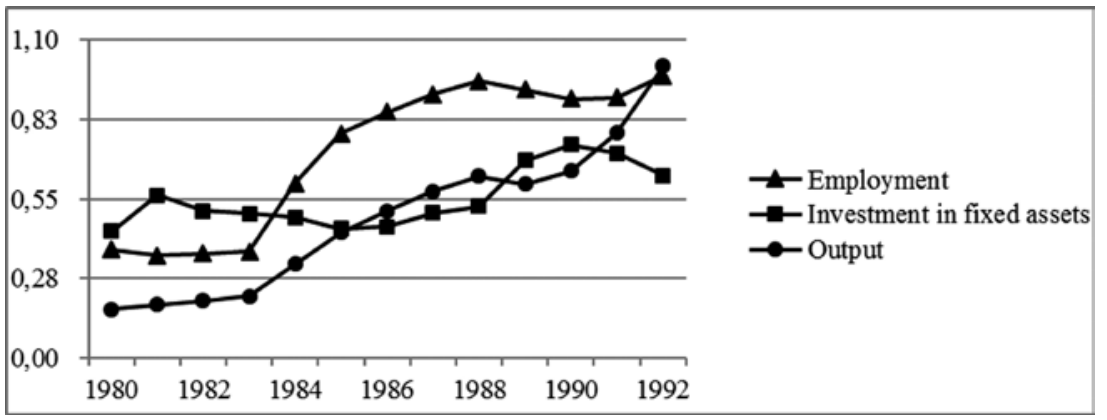

FIGURE 7 Industrial output, employment and investment in fixed assets of TVEs as ratio of SOES, 1980-1992.

SOURCE: NBS (1993, PP. 333-335).

enterprise to fulfill its plan targets and provide employment to urban workers, the soft budget constraint persisted, and public industry continued to lay claim to disproportionate shares of labor and capital. Although the inefficiency of SOE was partially offset by the rapid growth of TVEs (see Figure 7), public industry had gradually become an unsustainable burden on the central state.

Problems of inefficiency were compounded by the removal of price controls in 1985, which eroded SOE profitability. From 1985 to 1992, direct subsidies to loss-making SOE accounted for an average 3.2 percent of GDP. The actual costs of these loss-making enterprises were much higher still due to indirect transfers in the form of unpaid credit and interest (Brandt and Zhu 2000). Simultaneously, the capacity of the central state to support unprofitable enterprise had become increasingly limited because of the marginalization of central state revenues. Not only had substitution of profit remittances for profit tax caused overall state revenue to drop considerably, but due to decentralization the national (as opposed to local) share of revenues had decreased even more rapidly.

All in all, the outcomes of economic development during the first stage of reform had been equivocal. On the one hand, reforms had resulted in a departure from the strategy of industrialization by way of agricultural expropriation in favor of a more balanced trajectory of development. The establishment of TVEs promoted the development of light industry and increased rural living standards. The introduction of market relations increased the productivity of the primary sector and improved the supply and quality of consumer goods. One the other hand, economic growth had been volatile and persistently resulted in macroeconomic imbalances. Moreover, reforms had failed to invigorate public industry, and in certain respects had exacerbated unpro- 
ductive behavior, as the expansion of managerial autonomy and the development of a market component along the plan economy had created ubiquitous opportunities for rent-seeking. The costs of such practices had fallen predominantly on an increasingly economically impotent central state.

\section{Conclusion}

Reforms in the late 1970s had been initiated with the explicit objective of departing from the Maoist strategy of accelerated industrialization in favor of a more balanced trajectory of reform. However, by the end of the first phase of reforms, the autonomy given to enterprise and the regulatory function attributed to market allocation had expanded far beyond the parameters of the vision espoused by Chen Yun in the late 1950s. Both ideological and economic developments had contributed to these profound changes in the leadership's perception of the project of economic reform. The disruption caused by the anti-rightist polemics of the Great Leap and the Cultural Revolution had instilled in Deng and his fellow leaders a vehement antipathy toward ideological excess. The purge of the Gang of Four signaled a reversal in the status of the relations of production and the productive forces. Although under Deng, leadership occasionally reiterated the importance of ideological work, the emphasis was unequivocally on the development of China's economic prowess through the adoption of efficient production technology and methods, and the improvement of the mechanisms of allocation and economic governance. With the introduction of "practice as the sole criterion of truth" as the major guideline for economic debate, and the "primary stage of socialism" as the official diagnosis of the contemporary state of the economic system, the Party created leeway for ideas both foreign and domestic, which would have previously been decried as rightist and therefore unacceptable.

In spite of this more liberal intellectual climate, the traditional socialist analysis of sectoral relations initially continued to provide the main framework for discussing China's economic development. Until the mid-198os, the prevailing understanding among state leadership was that the main purpose of reform was to ensure an appropriate relationship between accumulation and consumption, and regulate the composition of production. Within this context, market production and exchange were regarded as useful expedients to increase production within agriculture and light industry. However, soon after the initiation of reforms, it had become obvious that leadership had failed to align the objectives of sectoral adjustment and decentralized production. The devolution of financial authority prompted high investments in fixed capital, 
a comparative neglect of agriculture and the accumulation of excess productive capacity. The incompatibility of the objectives of decentralization and agricultural development resulted in a bifurcation between those advocating sectoral readjustments through recentralization and planned investment and those arguing that further expansion of market forces would promote greater productivity. However, because centralization stymied microeconomic performance and decentralization thwarted macroeconomic stability, neither was able to provide a satisfactory solution to China's economic predicaments. Moreover, the development of a market economy had precipitated the appearance of novel economic problems - most pressingly mounting inflation.

The inability of the extant paradigm - centered on the analysis of sectoral relations and the laws of value and planned, proportionate developmentprompted a search for novel alternatives amongst China's economists. Such an alternative had begun to take shape by the mid-1980s. These initial discussions, building on antecedent debates of pricing and the law of value, reflected the opinion that, through economic levers, such as price controls and taxation, the state would be able to indirectly coordinate productive efforts. This would ensure economic development would unfold in accordance within the Party's objectives while fiscal and operational autonomy would invigorate enterprise. This perspective was explicitly endorsed in 1984, when the state engaged in a comprehensive program of price liberalization. Reform, however, experienced a considerable setback when arbitrary differences in plan and market prices and soft budget constraints promoted rent-seeking among SOE, and excessive demand for capital caused severe inflationary pressure and a rapid decline in the fiscal capability of the central state.

The novel problem of inflation caused economists to take an interest in monetary and Keynesian theory. Compatibility with the Marxian analysis provided an initial breeding ground for these Western streams of economic thought-monetarism in particular. The emphasis within these theories on monetary and fiscal policy dovetailed with the state's novel orientation toward macro-control, prompting an increasing reliance on manipulation of money and credit supply. However, absent the separation of state and enterprise and the removal of price differences, attempts to maintain macroeconomic balance by way of indirect measures proved ineffective. As long as public ownership of the productive forces remained the principal substantiation of the socialist character of the Chinese economy, profound changes within state industry were impossible. Additionally, as demonstrated by the policies of Li Peng, conservative leadership continued to adhere to an essentially socialist framework, which considered inflation to ultimately cause sectoral imbalances. Throughout the first phase of reforms, policy remained characterized by the 
periodic alternation of decentralization and consolidation, causing economic development to progress by starts and fits. ${ }^{134}$ Nevertheless, much like the debate on adjustment and the reform of the 196os had laid the foundation for the changes introduced by Deng, the discussion of the 1980 s would provide much of the theoretical input for economic policy in the subsequent decades.

134 This see-saw process of reform and consolidation has been characterized by Richard Baum (1994) as a cycle of fang (releasing) and shou (contraction). 